\title{
Wpływ występowania dolegliwości bólowych kręgosłupa na jakość życia pielęgniarek - doniesienia wstępne
}

\author{
The impact of back pain on the nurses' quality of life- \\ a preliminary study
}

DOROTA WOLSKA', KAROLINA FILIPSKA ${ }^{2,3}$, BEATA HAOR ${ }^{4,5}$

\footnotetext{
${ }^{1}$ Oddział ogólnopsychiatryczny, Wojewódzki Szpital dla Nerwowo i Psychicznie Chorych w Świeciu

2 Koło Naukowe „Neuronauka” Zakład Pielęgniarstwa Neurologicznego i Neurochirurgicznego, Collegium Medicum im. Ludwika Rydygiera w Bydgoszczy

${ }^{3}$ Studia doktoranckie Zakład Pielęgniarstwa Neurologicznego i Neurochirurgicznego, Collegium Medicum im. Ludwika Rydygiera w Bydgoszczy

${ }^{4}$ Instytut Nauk o Zdrowiu PWSZ we Włocławku

5 Zakład Pielęgniarstwa Neurologicznego i Neurochirurgicznego, CM im. Ludwika Rydygiera w Bydgoszcz
}

DOI: http://dx.doi.org/10.21784/IwP.2018.015

ISSN: 2451-1846

\section{Streszczenie:}

Wstęp. Ból jest złożonym odczuciem, które wskazuje nam na cierpienie. Jest symptomem różnych jednostek chorobowych, ale i również stanowi aspekt fizjologiczny. Dolegliwości bólowe pojawiają się w różnych narządach i tkankach ciała. Dotyczą one również i kręgosłupa. W ciągu ostatnich lat częstotliwość ich występowania drastycznie wzrosła.

Cel. Celem pracy jest ukazanie problemu występowania dolegliwości bólowych kręgosłupa wśród personelu pielęgniarskiego ze szczególnym 
uwzględnieniem sytuacji go nasilających oraz sposobów radzenia sobie $\mathrm{z}$ nim.

Materiał i metody. Badaniami objęto grupę 50 pielęgniarek zatrudnionych na oddziałach zachowawczych oraz zabiegowych (odpowiednio 34 oraz 16 osób). W pracy wykorzystano kwestionariusz ankiety własnej.

Wyniki. Wszyscy ankietowani zgodnie stwierdzają, iż wykonywana praca pielęgniarki wpływa na występowanie dolegliwości bólowych kręgosłupa. Natomiast dokładnie połowa ankietowanych była zdania, że ból kręgosłupa może być powodem czasowej niezdolności do pracy - 25 osób (50,0\%). Jako najczęstszą czynnością nasilającą ból okazało się podnoszenie $(40,9 \%)$ oraz schylanie (30,9\%). Największy odsetek ankietowanych radzi sobie z bólem przyjmując leki przeciwbólowe $(31,4 \%)$. Wyższą średnią natężenia odczuwanych dolegliwości bólowych odnotowano u respondentów w grupie z bólem w odcinku lędźwiowym kręgosłupa. Otrzymane różnice nie okazały się jednak istotne statystycznie.

Wnioski. W związku z drastycznym wzrostem występowania dolegliwości bólowych kręgosłupa wśród społeczeństwa należy duży nacisk położyć na podnoszenie świadomości oraz wiedzy na temat tego schorzenia. W grupie zwiększonego ryzyka znajdują się $w$ główniej mierze pielęgniarki/pielęgniarze, dlatego uświadamianie tej grupy zawodowej jest tak istotne.

Słowa kluczowe: personel pielęgniarski, jakość życia, ból

\begin{abstract}
:
Introduction. Pain sensation is complex. It signals distress. It is a symptom of various disease entities, but also a physiological aspect. Pain sensations occur in various organs and tissues of the body. They also affect the areas of spine. Over the last years the frequency of back pain occurrence has increased dramatically.

Aim. The study aims at showing the existence of the problem of back pain among nurses with special reference to the situation escalating it and different ways of dealing with it.

Material and methods. The study included a group of 50 nurses working on the conservative wards surgical wards. (respectively 34 and 16 people). A questionnaire of our own design was used.
\end{abstract}


Results. All the respondents state that nurses work done affects the occurrence of back pain, while half of the respondents thought that back pain could be a reason for temporary inability to work - 25 people (50.0\%).Lifting $(40.9 \%)$ and bending $(30.9 \%)$ were defined as the most common activities intensifying pain. The highest percentage of respondents cope with pain by taking painkillers $(31.4 \%)$. A higher severity of pain was reported in the group of patients with pain in the lumbar region of the spine. The differences obtained, however, did not turn out to be statistically significant.

Conclusions. In view of the drastic increase in the occurrence of back pain among the public the emphasis should be placed on raising awareness and knowledge about the disease. Nurses are at an increased risk , therefore, the awareness of this professional group is so important.

Keywords: nursing staff, quality of life, pain

\section{Wstęp}

Ból jest złożonym odczuciem, które wskazuje nam na cierpienie. Jest symptomem różnych jednostek chorobowych, ale i również stanowi aspekt fizjologiczny [1]. Bardzo często zmusza do zmniejszenia aktywności na różnych polach życiowych [2]. Ból posiada trzy główne cechy. Zawsze jest nieprzyjemny, za każdym razem ma usposobienie psychiczne oraz somatyczne. Podłożem odczuwanych dolegliwości jest przeszłość (odczucia wcześniej doznane na zasadzie doświadczenia), teraźniejszość (uszkodzenie tkanki w danym momencie) oraz przyszłość [3]. Ból cechuje się nieprzyjemnym odczuciem zmysłowym oraz emocjonalnym, jest przyczyną rzeczywistego bądź potencjalnego uszkodzenia tkanek $[1,4]$.

Dolegliwości bólowe pojawiają się w różnych narządach i tkankach ciała. Dotyczą one również i kręgosłupa. W ciągu ostatnich lat częstotliwość ich występowania drastycznie wzrosła. Bóle odcinka lędźwiowo-krzyżowego po 30 roku życia, zwiększają swoją częstotliwość, a największą osiągają w 55-64 roku życia. Dolegliwości bólowe obecne są zarówno u kobiet, jak i u mężczyzn z porównywalną 
częstotliwością, lecz u kobiet odnotowano, że wraz z zaawansowaniem wieku występują częściej [5,6].

Do tej pory przedstawiono różne przyczyny bólów lędźwiowokrzyżowych, które stanowią główny powód zmniejszenia zawodowej aktywności osób poniżej 45 r. ż. W grupie osób w wieku 50-64 lat wśród przyczyn dominują tylko choroby kardiologiczne i schorzenia reumatyczne. Okazuje się, że $\mathrm{w}$ trakcie przerwy od pracy spowodowanej bólem kręgosłupa, która trwa dłużej niż 6 miesięcy tylko $50 \%$ osób wraca do pracy zawodowej a po 12 miesiącach zaledwie $25 \%$ osób. Istotny jest także fakt, iż ból stanowi główną determinantę jakości życia powodując w konsekwencji obniżenie sprawności zawodowej, fizycznej i społecznej [5-9].

Celem badań jest ukazanie problemu występowania dolegliwości bólowych kręgosłupa wśród personelu pielęgniarskiego ze szczególnym uwzględnieniem sytuacji, które nasilają ich wystepowanie oraz sposobów radzenia sobie z nimi.

\section{Materiał i metody}

Badaniami objęto grupę 50 pielęgniarek zatrudnionych na oddziałach zachowawczych oraz zabiegowych (odpowiednio 34 oraz 16 osób). Liczba kobiet wyniosła 48 osób tj. 98,0\%. Badanych podzielono na trzy grupy wiekowe: do 40 lat, 41-50 lat oraz powyżej 50 lat. Najliczniejszą grupę stanowili respondenci w wieku 41-50 lat 22 osoby $(44,0 \%)$, najmniej liczną tworzyli ankietowani w wieku do 40 lat - 9 osób $(18,0 \%)$. Na oddziale zabiegowym odnotowano dwie równoliczne grupy wiekowe: 41-50 lat oraz powyżej 50 lat po 6 osób (po 37,5\%). Na oddziale zachowawczym najliczniejszy przedział respondentów dotyczył wieku 41-50 lat - 16 osób (47,1\%). Z kolei najmniej liczny - do 40 lat - 5 osób (14,7\%). Ponad połowa respondentów to mieszkańcy miasta - 34 osoby $(68,0 \%)$. Większość respondentów tj. 66,0\% deklarowała wykształcenie średnie, natomiast wykształcenie wyższe- $34 \%$. 
Uczestnicy przed przystąpieniem do badania zapoznali się z przygotowaną instrukcją i informacją dla uczestnika badania naukowego. Podpisali także świadomą zgodę na udział $\mathrm{w}$ badaniu naukowym. W pracy wykorzystano kwestionariusz ankiety własnej. Pytania dotyczyły dolegliwości bólowych występujących w obrębie kręgosłupa z uwzględnieniem sytuacji go nasilających oraz sposobów radzenia sobie z nim. Wszystkie obliczenia i ryciny wykonano przy użyciu programu Statistica 10.0 i arkusza kalkulacyjnego Microsoft Excel. Przyjęto poziom istotności $\mathrm{p} \leq 0,05$.

\section{Wyniki}

Wszyscy uczestnicy badania zgodnie stwierdzili, iż praca zawodowa może wpływać na nasilenie dolegliwości bólowych kręgosłupa w odcinku krzyżowym kręgosłupa (Tabela 1).

Tabela 1. Wpływ pracy zawodowej na nasilenie się dolegliwości bólowych kręgosłupa w odcinku krzyżowym w opinii badanych.

\begin{tabular}{|l|l|l|l|l|l|l|}
\hline oddział & \multicolumn{2}{l|}{ zabiegowy } & \multicolumn{2}{l|}{ zachowawczy } & \multicolumn{2}{l|}{ razem } \\
\hline odpowiedź & liczba & $\%$ & liczba & $\%$ & liczba & $\%$ \\
\hline tak & 16 & 100,0 & 34 & 100,0 & 50 & 100,0 \\
\hline nie & 0 & 0,0 & 0 & 0,0 & 0 & 0,0 \\
\hline Razem & 16 & 100,0 & 34 & 100,0 & 50 & 100,0 \\
\hline
\end{tabular}

Źrodło: wynik badań własnych

Dokładnie połowa ankietowanych była zdania, że ból kręgosłupa może być powodem czasowej niezdolności do pracy 25 osób (50,0\%). Identycznie rozłożyły się odpowiedzi na poszczególnych oddziałach. Na oddziale zabiegowym potwierdziło 
to - 8 osób $(50,0 \%)$,a na oddziale zachowawczym - 17 osób $(50,0 \%)$. Odpowiedzi ankietowanych zostały zaprezentowane w Tabeli 2.

Tabela 2. Ból kręgosłupa jako powód czasowej niezdolności do pracy w opinii badanych.

\begin{tabular}{|l|l|l|l|l|l|l|}
\hline oddział & \multicolumn{2}{l|}{ zabiegowy } & \multicolumn{3}{l|}{ zachowawczy } & \multicolumn{2}{l|}{ razem } \\
\hline odpowiedź & liczba & $\%$ & liczba & $\%$ & liczba & $\%$ \\
\hline tak & 8 & 50,0 & 17 & 50,0 & 25 & 50,0 \\
\hline nie & 8 & 50,0 & 17 & 50,0 & 25 & 50,0 \\
\hline Razem & 16 & 100,0 & 34 & 100,0 & 50 & 100,0 \\
\hline
\end{tabular}

Źrodło: wynik badań własnych

Odpowiadając na pytanie o sytuacje nasilające ból respondenci zaznaczali po kilka stwierdzeń. Łącznie od 50 osób badanych odnotowano 110 odpowiedzi, średnio - 2,2 odpowiedzi. Na oddziale zabiegowym od 16 ankietowanych odnotowano - 34 odpowiedzi, średnio - 2,12 odpowiedzi, na oddziale zachowawczym od 34 respondentów uzyskano - 76 odpowiedzi, średnio 2,23 odpowiedzi. Najczęściej badani zaznaczali, że ból nasila się przy podnoszeniu - 45 osób, co stanowiło 40,9\% wszystkich zaznaczonych stwierdzeń. W najmniejszym stopniu nasilenie dolegliwości pojawiało się podczas siedzenia - 2 osoby $(1,8 \%)$. Na oddziale zabiegowym najczęściej bóle spowodowane były przez podnoszenie - 14 osób $(41,2 \%)$, a najrzadziej wynikały one z pozycji siedzącej - 1 osoba $(2,9 \%)$. Na oddziale zachowawczym czynnością, która miała największy wpływ na dolegliwości kręgosłupa było podnoszenie 31 osób $(40,8 \%)$, a najmniejszą siedzenie - 1 osoba $(1,3 \%)$. Na jedną sytuację, która nasila ból wskazała - 1 osoba (0/1), na dwie - 38 osób $(14 / 24)$ i na trzy - 11 osób (2/9) (Tabela 3). 
Tabela 3. Sytuacje nasilające odczuwanie bólu przez badanych.

\begin{tabular}{|l|l|l|l|l|l|l|}
\hline oddział & \multicolumn{2}{|l|}{ zabiegowy } & \multicolumn{3}{l|}{ zachowawczy } & \multicolumn{2}{l|}{ razem } \\
\hline sytuacja & liczba & $\%$ & liczba & $\%$ & liczba & $\%$ \\
\hline schylanie & 8 & 23,5 & 26 & 34,2 & 34 & 30,9 \\
\hline podnoszenie & 14 & 41,2 & 31 & 40,8 & 45 & 40,9 \\
\hline stanie & 11 & 32,4 & 18 & 23,7 & 29 & 26,4 \\
\hline siedzenie & 1 & 2,9 & 1 & 1,3 & 2 & 1,8 \\
\hline Razem & 34 & 100,0 & 76 & 100,0 & 110 & 100,0 \\
\hline
\end{tabular}

Źródło: wynik badań własnych

Odpowiadając na pytanie o sposoby radzenia sobie z bólem kręgosłupa ankietowani zaznaczali po kilka stwierdzeń. Łącznie od 50 osób odnotowano 121 odpowiedzi. Średnio - 2,42 odpowiedzi. $\mathrm{Na}$ oddziale zabiegowym od 16 osób odnotowano - 37 odpowiedzi, średnio - 2,31 odpowiedzi, na oddziale zachowawczym od 34 badanych wykazano - 84 odpowiedzi, średnio - 2,47 odpowiedzi. Najczęstszą metodą radzenia sobie z bólem kręgosłupa było przyjmowanie leków przeciwbólowych - 38 osób, co stanowiło 31,4\% wszystkich zaznaczonych odpowiedzi. W dalszej kolejności badani wskazywali na zmniejszenie aktywności oraz rozciąganie i wzmacnianie mięśni kręgosłupa - po 28 osób (po 23,1\%). W najmniejszym stopniu korzystali z technik relaksacyjnych - 7 osób (5,8\%). Na oddziale zabiegowym najczęściej ankietowanych podawało zmniejszenie aktywności - 12 osób (32,4\%). Najrzadziej respondenci zaznaczalikorzystanie z pomocy lekarza - 5 osób $(13,5 \%)$. Osoby badane nie wskazywały na techniki relaksacyjne. Na oddziale zachowawczym 
główną czynnością, która pomagała w zmniejszaniu bólu ze strony kręgosłupa było przyjmowanie leków przeciwbólowych - 28 osób $(33,3 \%)$. W najmniejszym stopniu badani zaznaczyli korzystanie z technik relaksacyjnych - 7 osób (8,3\%). Żadna z osób badanych nie wskazała jednego sposobu radzenia sobie z bólem kręgosłupa. Dwa sposoby podało- 30 osób (11/193), trzy - 19 osób (5/14) i cztery 1 osoba $(0 / 1)$ (Tabela 4$)$.

Tabela 4. Sposoby radzenia sobie z bólem kręgosłupa.

\begin{tabular}{|c|c|c|c|c|c|c|}
\hline \multirow{2}{*}{\begin{tabular}{|l} 
oddział \\
sposób
\end{tabular}} & \multicolumn{2}{|c|}{ zabiegowy } & \multicolumn{2}{|c|}{$\begin{array}{l}\text { zachowawcz } \\
\mathbf{y}\end{array}$} & \multicolumn{2}{|c|}{ razem } \\
\hline & $\begin{array}{l}\text { liczb } \\
\mathbf{a}\end{array}$ & $\%$ & $\begin{array}{l}\text { liczb } \\
\mathbf{a}\end{array}$ & $\%$ & $\begin{array}{l}\text { liczb } \\
\mathbf{a}\end{array}$ & $\%$ \\
\hline $\begin{array}{l}\text { przyjmowanie } \\
\text { leków przeciwbólowych }\end{array}$ & 10 & 27,0 & 28 & 33,3 & 38 & 31,4 \\
\hline $\begin{array}{l}\text { zmniejszenie } \\
\text { aktywności }\end{array}$ & 12 & 32,4 & 16 & 19,0 & 28 & 23,1 \\
\hline $\begin{array}{l}\text { rozciąganie } \\
\text { oraz wzmacnianie } \\
\text { mięśni kręgosłupa }\end{array}$ & 10 & 27,0 & 18 & 21,4 & 28 & 23,1 \\
\hline $\begin{array}{ll}\text { korzystanie } & \\
\mathrm{z} & \text { technik } \\
\text { relaksacyjnych } & \end{array}$ & 0 & 0,0 & 7 & 8,3 & 7 & 5,8 \\
\hline $\begin{array}{l}\text { korzystanie } \\
\text { z pomocy lekarza }\end{array}$ & 5 & 13,5 & 15 & 17,9 & 20 & 16,5 \\
\hline Razem & 37 & $\begin{array}{l}100 \\
0\end{array}$ & 84 & 100,0 & 121 & $\begin{array}{l}100 \\
0\end{array}$ \\
\hline
\end{tabular}

Źrodło: wynik badań własnych

Wyższą średnią natężenia odczuwanych dolegliwości bólowych odnotowano $\mathrm{u}$ respondentów $\mathrm{w}$ grupie $\mathrm{z}$ bólem $\mathrm{w}$ odcinku lędźwiowym kręgosłupa - 5,27 punktu, a wśród ankietowanych 
odczuwających ból w odcinku krzyżowym kręgosłupa- 4,53 punktu (Tabela 5, Rycina 1).

Tabela 5. Średnie wyniki związane $\mathrm{z}$ odczuwaniem bólu w zależności od jego lokalizacji.

\begin{tabular}{|l|l|l|l|l|l|l|l|l|l|l|}
\hline $\begin{array}{l}\text { kręgosłu } \\
\mathbf{p}\end{array}$ & $\mathbf{N}$ & $\begin{array}{l}\text { Średni } \\
\mathbf{a}\end{array}$ & $\mathbf{S D}$ & $\begin{array}{l}\text { Ufnoś } \\
\mathbf{c} \\
\mathbf{9 5 , 0} \\
\mathbf{\%}\end{array}$ & $\begin{array}{l}\text { Ufność } \\
\mathbf{+ 9 5 , 0} \\
\mathbf{\%}\end{array}$ & $\begin{array}{l}\text { minimu } \\
\mathbf{m}\end{array}$ & $\begin{array}{l}\text { maksimu } \\
\mathbf{m}\end{array}$ & $\begin{array}{l}\mathbf{Q 2} \\
\mathbf{5}\end{array}$ & $\begin{array}{l}\text { median } \\
\mathbf{a}\end{array}$ & $\begin{array}{l}\mathbf{Q 7} \\
\mathbf{5}\end{array}$ \\
\hline $\begin{array}{l}\text { lędźwiow } \\
\mathbf{y}\end{array}$ & 3 & 5,27 & $\begin{array}{l}1,80 \\
4\end{array}$ & 4,59 & 5,94 & 1,0 & 9,0 & 4,0 & 5,0 & 6,0 \\
\hline $\begin{array}{l}\text { krzyżow } \\
\text { y }\end{array}$ & $\begin{array}{l}2 \\
0\end{array}$ & 4,53 & $\begin{array}{l}1,68 \\
2\end{array}$ & 3,74 & 5,31 & 2,0 & 7,5 & 3,0 & 5,0 & 5,5 \\
\hline
\end{tabular}




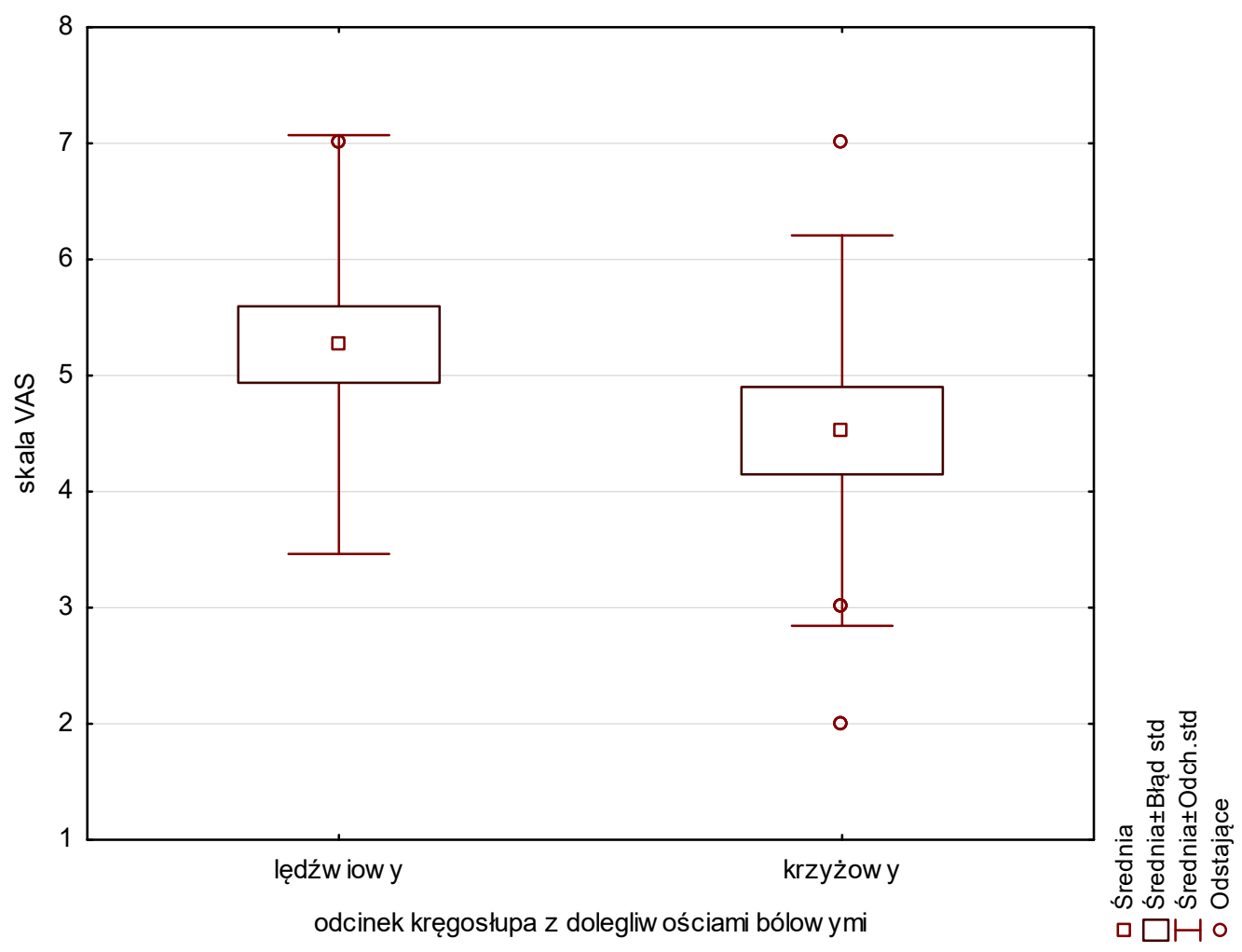

Rycina 1. Odczuwanie dolegliwości bólowych kręgosłupa w zależności od lokalizacji jego występowania.

Źrodło: wynik badań własnych

Ze względu na poziom istotności $(p>0,05)$ u badanych nie odnotowano statystycznie istotnej różnicy pomiędzy miejscem odczuwanych dolegliwości bólowych a jego oceną, zarówno w odniesieniu do wszystkich respondentów, jak i badanych w poszczególnych oddziałach (Tabela 6). 
Tabela 6. Różnica $w$ wynikach związana $z$ odczuwaniem dolegliwości bólowych $w$ zależności od miejsca jego występowania.

\begin{tabular}{|c|c|c|c|c|c|c|c|c|c|c|}
\hline pozycja & \begin{tabular}{|l} 
Sum.r \\
ang \\
krzyżo \\
wy
\end{tabular} & $\begin{array}{l}\text { Sum.ra } \\
\text { ng } \\
\text { lędźwi } \\
\text { owy }\end{array}$ & $\mathbf{U}$ & Z & $\begin{array}{l}\text { pozio } \\
\text { m p }\end{array}$ & $\begin{array}{l}\text { Z } \\
\text { popr } \\
\text { aw }\end{array}$ & $\begin{array}{l}\text { pozio } \\
\text { m p }\end{array}$ & $\begin{array}{l}\text { N } \\
\text { ważn. } \\
\text { krzyżo } \\
\text { wy }\end{array}$ & $\begin{array}{l}\text { N } \\
\text { ważn. } \\
\text { lędźwi } \\
\text { owy }\end{array}$ & $\begin{array}{l}2 * 1 \\
\text { str } \\
\text { dok } \\
\text { l. p. }\end{array}$ \\
\hline razem & 436,0 & 839,0 & $\begin{array}{l}226 \\
, 0\end{array}$ & $\begin{array}{l}- \\
1,45 \\
6\end{array}$ & 0,146 & - & 0,139 & 20 & 30 & $\begin{array}{l}0,14 \\
7\end{array}$ \\
\hline $\begin{array}{l}\text { zabiegow } \\
\text { y }\end{array}$ & 95,0 & 41,0 & $\begin{array}{l}26 \\
0\end{array}$ & $\begin{array}{l}0,11 \\
3\end{array}$ & 0,910 & 0,115 & 0,908 & 11 & 5 & $\begin{array}{l}0,91 \\
3\end{array}$ \\
\hline $\begin{array}{l}\text { zachowa } \\
\text { wczy }\end{array}$ & 111,0 & 484,0 & $\begin{array}{l}66, \\
0\end{array}$ & $\begin{array}{l}1,79 \\
6\end{array}$ & 0,073 & $\begin{array}{l}- \\
1,829\end{array}$ & 0,067 & 9 & 25 & $\begin{array}{l}0,07 \\
2\end{array}$ \\
\hline
\end{tabular}

*Test U Manna-Whitneya

Źródło: wynik badań własnych

\section{Dyskusja}

Zawód pielęgniarki związany jest $\mathrm{z}$ obciążeniem zarówno fizycznym, jak i psychicznym Obciążenie fizyczne dotyczy głównie czynności takich jak: przewożenie pacjentów wykonywanie zabiegów pielęgnacyjno- higienicznych [10]. Częstym powodem bólu, który jest odczuwany przez pielęgniarki, jest osłabiony oraz nieprawidłowo przygotowany mięśniowo-więzadłowy aparat, który nie potrafi poradzić sobie z zadaniami, które przerastają możliwości fizjologiczne. Powoduje to pojawienie się mikrourazów oraz trwałe patologiczne modyfikacje, które tworzą się w obszarze struktur dolnego odcinka kręgosłupa [7]. Dolegliwości bólowe kręgosłupa pojawiają się w trakcie wykonywania pracy w pozycji stojącej, ale również siedzącej. Pielęgniarki bardzo często przy realizacji czynności zawodowych przyjmują nieprawidłową pozycję ciała. Jest ona wymuszona i dlatego też kręgosłup jest narażony na obciążenia. Nieustanne powtarzanie czynności przyczynia się do występowania przewlekłych bólów kręgosłupa [11]. 
Wszyscy uczestnicy przeprowadzonego przez nas badania zgodnie stwierdzili, iż praca zawodowa może wpływać na nasilenie dolegliwości bólowych kręgosłupa w odcinku krzyżowym kręgosłupa. Natomiast dokładnie połowa ankietowanych była zdania, że ból kręgosłupa może być powodem czasowej niezdolności do pracy 25 osób (50,0\%). W badaniach przeprowadzonych przez Karahan i wsp. [12] wśród 1600 pracowników szpitali blisko 65,8\% doznawało dolegliwości bólowych kręgosłupa w odcinku krzyżowym. Najbardziej narażoną grupą zawodową na występowanie schorzeń kręgosłupa okazali się pielęgniarze/pielęgniarki (77,1\%). W większości przypadków (78,3\%) ból kręgosłupa pojawił się po tym, jak respondenci rozpoczęli pracę $\mathrm{w}$ służbie zdrowia. Wiek, płeć żeńska, palenie tytoniu, zawód, stres okazały się statystycznie istotnymi czynnikami ryzyka $(\mathrm{p}<0,05)$. Z kolei w badaniach przeprowadzonych przez Skela-Savič i wsp. [13] wśród 1744 pracowników personelu pielęgniarskiego blisko $85,9 \%$ skarżyło się na występowanie dolegliwości bólowych odcinka krzyżowego kręgosłupa.

Wyższą średnią odczuwania dolegliwości bólowych odnotowano $\mathrm{u}$ respondentów $\mathrm{w}$ grupie $\mathrm{z}$ bólem $\mathrm{w}$ odcinku lędźwiowym kręgosłupa. Natomiast nie odnotowano statystycznie istotnej różnicy pomiędzy miejscem odczuwania dolegliwości bólowych i jego oceną $(p>0,05)$. K. Juraszek i wsp. [14] zbadali 205 pielęgniarek pod kątem oceny dolegliwości bólowych kręgosłupa. Autorzy wykazali, że występowanie oraz lokalizacja tych dolegliwości jest zależna od charakteru wykonywanej pracy. Niemniej jednak ból kręgosłupa najczęściej obejmował okolicę lędźwiowo-krzyżową kręgosłupa. E. Przychodzka E. oraz R. Lorencowicz [15] oceniały problem zespołów bólowych kręgosłupa wśród 101 czynnych zawodowo pielęgniarek. Badania wskazały, że $80 \%$ pielęgniarek przyznaje, że występuje u nich problem dolegliwości ze strony kręgosłupa. Pod względem lokalizacji odcinkiem najbardziej objętym dolegliwościami bólowymi był odcinek lędźwiowo-krzyżowy (55,45\%). 
W przeprowadzonym badaniu odpowiadając na pytanie dotyczące sytuacji nasilających ból respondenci zaznaczali po kilka stwierdzeń. Najczęściej badani zaznaczali, że ból nasila się przy podnoszeniu - 45 osób, co stanowiło $40,9 \%$ wszystkich zaznaczonych stwierdzeń. $W$ najmniejszym stopniu nasilenie dolegliwości pojawiało się podczas siedzenia - 2 osoby $(1,8 \%)$. W badaniu przeprowadzonym przez d'Errico i wsp. [16] częstość występowania bólów krzyża wśród 174 pielęgniarek wyniosła 58\%. Respondenci również przyznali, iż dość częste pochylanie się wzmaga występowanie dolegliwości bólowych. Z kolei w badaniach przeprowadzonych przez Klimaszewską i wsp. [17] ból kręgosłupa według kobiet nasila się podczas wykonywania pracy $\mathrm{w}$ ruchu, natomiast według mężczyzn podczas siedzenia.

\section{Wnioski}

1. Wszyscy ankietowani zgodnie stwierdzają, iż wykonywana praca pielęgniarki wpływa na występowanie dolegliwości bólowych kręgosłupa.

2. Dokładnie połowa ankietowanych była zdania, że ból kręgosłupa może być powodem czasowej niezdolności do pracy - 25 osób (50,0\%).

3. Najczęstszą czynnością nasilającą ból okazało się podnoszenie $(40,9 \%)$ oraz schylanie $(30,9 \%)$.

4. Jedną z najbardziej popularnych metod radzenia sobie z bólem kręgosłupa było przyjmowanie leków przeciwbólowych $(31,4 \%)$.

5. Wyższą średnią odczuwania dolegliwości bólowych odnotowano u respondentów z bólem w odcinku lędźwiowym kręgosłupa.

6. Nie odnotowano statystycznie istotnej różnicy pomiędzy miejscem odczuwanych dolegliwości bólowych a nasileniem bólu. 


\section{Zalecenia dla praktyki pielęgniarskiej}

Przeprowadzone badania pozwalają ukazać problem występowania dolegliwości bólowych kręgosłupa wśród pielęgniarek/pielęgniarzy. Pielęgniarki są grupą zawodową, która jest wyjątkowo narażona na obciążenia układu mięśniowo-szkieletowego. Niezbędne jest precyzyjne rozpoznanie kliniczne, właściwy dobór sposobu leczenia, ale i również reagowania podczas pojawiania się pierwszych objawów, dlatego tak istotna jest edukacja personelu pielęgniarskiego na temat $\mathrm{w} / \mathrm{w}$ schorzenia.

\section{Bibliografia / Bibliography:}

1. Domżał T. Przewlekłe nieswoiste bóle krzyża- stara dolegliwość czy nowa choroba neurologiczna? Pol Przegl Neurol. 2007;3(4):216-227.

2. Dobrogowski J., Zajączkowska R., Dutka J., Wordliczek J. Patofizjologia i klasyfikacja bólu. Pol Przegl Neurol. 2011;7(1):20-30.

3. Koszewski W. Bóle kręgosłupa i ich leczenie. Wydawnictwo Medyczne Termedia, Poznań 2010.

4. Sieradzki M., Krajewska-Kułak E., Van Damme-Ostapowicz K. Ocena występowania zespołów bólowych dolnego odcinka kręgosłupa w populacji studentów fizjoterapia. Probl Hig Epidemiol. 2013;94(3):451-458.

5. Wójcik A, Martowicz B. Zespoły bólowe odcinka lędźwiowokrzyżowego. Think. 2012;2(10):50-63.

6. Milanow J. Zespół bólowy kręgosłupa. Pediatr Med Rodz. 2014;10(3):253-264. 
7. Styczyński T. Postępy w leczeniu choroby zwyrodnieniowej kręgosłupa. Reumatologia. 2013;51(6):429-436.

8. Depa A., Drużbicki M. Ocena częstości występowania zespołów bólowych lędźwiowego odcinka kręgosłupa w zależności od charakteru wykonywanej pracy. Przegl Med Uniw Rzesz. 2008;1:34-41.

9. Hanus-Atras K., Iłżecka J. Bóle kręgosłupa- przyczyny, postępowanie. Med Ogól. 2016;16:315-322.

10. Leszczyńska A., Daniszewska B., Dudek K., Chrzanowska-Rydz M. Szmagaj J., Kujawa J. Wpływ ergonomii pracy pielęgniarek na występowanie dolegliwości bólowych $\mathrm{w}$ obrębie kręgosłupa. Kwart Ortop. 2008;2:210-218.

11. Bugajska J., Żołnierzyk-Zdreda D., Hildt-Ciupińska K. Profilaktyka dolegliwości mięśniowo-szkieletowych w kontekście psychospołecznych aspektów pracy. Bezpieczeństwo Pracy. 2011;4:12-15.

12. Karahan A., Kav S., Abbasoglu A., Dogan N. Low back pain: prevalence and associated risk factors among hospital staff. J Adv Nurs. 2009;65(3):516-24.

13. Skela-Savič $\quad$ B., Pesjak $\quad$ K., Hvalič-Touzery $\quad$ S. Low back pain among nurses in Slovenian hospitals: cross-sectional study. Int Nurs Rev. 2017;64(4):544-551.

14. Juraszek K., Hagner -Derengowska., Hoffmann M., Kalisz Z., Zukow W. Wpływ pracy zawodowej na występowanie zespołów bólowych kręgosłupa na przykładzie pielęgniarek województwa Kujawkopomorskiego. Journal of Education, Health and Sport. 2016;6(8):504521. 
15. Przychodzka E., Leorenowicz R., Grądek E., Turowski K., Jasik J. Problem bólu kręgosłupa u czynnych zawodowo pielęgniarek. Zdrowie i Dobrostan. 2014;2:135-147.

16. d'Errico A., Viotti S., Baratti A., Mottura B., Barocelli A.P., Tagna $\begin{array}{llll}\text { M., Sgambelluri } & \text { B., Battaglino } & \text { P., Converso } & \text { D. Low back }\end{array}$ pain and associated presenteeism among hospital nursing staff. J ccup Health. 2013;55(4):276-83.

17. Klimaszewska K., Krajewska-Kułak E., Kondzior D., Kowalczuk K., Jankowiak K. Jakość życia pacjentów z zespołami bólowymi odcinka lędźwiowego kręgosłupa. Problemy Pielęgniarstwa. 2011;19(1):47-54. 